\title{
Konstruksi Penataan Daerah dan Model Pembagian Urusan Pemerintahan
}

\section{Sherlock Halmes Lekipiouw}

Fakultas Hukum Universitas Pattimura, Ambon, Indonesia

E-mail: lekipiouw.sherlock@gmail.com

\begin{tabular}{|c|c|}
\hline Dikirim: 30/07/202C & Dipublikasi: 30/12/2020 \\
\hline Info Artikel & Abstract \\
\hline $\begin{array}{l}\text { Keywords: } \\
\text { Regional } \\
\text { Arrangement; } \\
\text { Division Model; } \\
\text { Government Affairs. }\end{array}$ & $\begin{array}{l}\text { Regional arrangement and distribution model of governmental affairs. } \\
\text { The purpose of this research is to provide clarity regarding the legal } \\
\text { interpretation of the formulation of norms in regional government laws. } \\
\text { Research methods The research method uses normative research } \\
\text { through a conceptual approach and a statue approach. The results } \\
\text { showed that the development of decentralization into a state } \\
\text { administration system had an impact on local government institutions, } \\
\text { one of which was the distribution pattern of government affairs. Thus, } \\
\text { comparing the distribution of functions is not possible without the } \\
\text { overall decentralized institutional framework developed by a country. } \\
\text { From this, a comprehensive framework of decentralization institutions } \\
\text { and local government is needed. It also does not rule out the possibility } \\
\text { for a region to propose governmental affairs that become its specialty, } \\
\text { both on a provincial and regional scale. The concept of division of } \\
\text { functions is carried out dynamically, where regions can carry out real } \\
\text { government affairs (needed and in accordance with regional } \\
\text { capacities). It should be possible for districts / cities to propose } \\
\text { governmental affairs that are needed or not needed; who can or cannot } \\
\text { be arrested. Decentralization can only work if it is based on a number } \\
\text { of preconditions, namely a capable and effective central government. } \\
\text { Therefore, it is necessary to review various regulations that are not in } \\
\text { line with the principle of broadest autonomy. }\end{array}$ \\
\hline & ADstrak \\
\hline $\begin{array}{l}\text { Kata Kunci: } \\
\text { Penataan Daerah; } \\
\text { Model Pembagian; } \\
\text { Urusan } \\
\text { Pemerintahan. }\end{array}$ & $\begin{array}{l}\text { Penatan daerah dan model pembagian urusan pemerintahan. Tujuan dari } \\
\text { penelitian ini yaitu memberikan kejelasan mengenai penafsiran hukum } \\
\text { atas rumusan norma dalam undang-undang pemerintahan daerah. } \\
\text { Metode penelitian Metode penelitian menggunakan penelitian normatif } \\
\text { melalui pendekatan konseptual (conceptual approach) dan pendekatan } \\
\text { perundang-undangan (statue approach). Hasil penelitian menunjukan } \\
\text { bahwa perkembangan desentralisasi menjadi sistem ketatanegaraan } \\
\text { berdampak pada kelembagaan pemerintahan daerah, yang merupakan } \\
\text { suatu model sebagai salah satu pembagian urusan pemerintahan, dengan } \\
\text { demikian, sebagai perbandingan pembagian fungsi tidak mungkin } \\
\text { dilakukan tanpa kerangka kelembagaan desentralisasi secara }\end{array}$ \\
\hline
\end{tabular}


DOI:

10.47268/sasi.v26i4.414

keseluruhan yang dikembangkan oleh suatu negara. Dari sini diperlukan kerangka kerja yang komprehensif dari lembaga desentralisasi dan pemerintahan daerah. Tidak menutup kemungkinan pula bagi suatu daerah untuk mengajukan urusan pemerintahan yang menjadi kekhususannya, baik dalam skala provinsi maupun regional. Konsep pembagian urusan dilakukan secara dinamis, dimana daerah dapat melaksanakan urusan pemerintahan secara nyata (dibutuhkan dan sesuai dengan kemampuan daerah). Seharusnya mungkin kabupaten / kota mengajukan urusan pemerintahan yang dibutuhkan atau tidak diperlukan; siapa yang bisa atau tidak bisa ditahan. Desentralisasi hanya dapat berjalan jika dilandasi oleh sejumlah prasyarat, yaitu pemerintah pusat yang mampu dan efektif. Oleh karena itu, perlu dikaji ulang berbagai regulasi yang tidak sejalan dengan prinsip otonomi seluasluasnya.

\section{A. PENDAHULUAN}

Penyelenggaraan sistem pemerintahan di daerah merupakan suatu hal yang sangat sakral karena menyangkut tatanan dan keutuhan Negara kesatuan. ${ }^{1}$ Penyelenggaraan pemerintahan dalam konsep hubungan antara pemerintah pusat dan daerah, secara filosofis bertumpuh pada tujuan negara sebagaimana dimaksud pada alenea ketiga dan keempat Pembukaan UUD NRI Tahun 1945. Pengaturan mengenai hubungan antara pusat dan daerah dalam tataran teoritis berkaitan dengan pembagian kekuasaan secara horizontal dan vertikal. Pembagian kekuasaan secara horizontal merupakan pembagian kekuasaan, dimana kekuasaan dalam suatu negara dibagi dan diserahkan kepada cabang kekuasaan negara yakni kekuasaan eksekutif (pemerintahan), kekuasaan legislatif (parlamen) dan kekuasaan yudikatif (badan peradilan). Sementara itu, pembagian kekuasaan secara vertikal yaitu pembagian kekuasaan antara pemerintah pusat (nasional) dan satuan pemerintahan yang lebih rendah (pemerintah daerah).

Berangkat dari konstruksi Pasal 1 ayat (1) UUD NRI Tahun 1945, jelas terlihat bahwa konsep negara kesatuan merupakan lasandan konstitusional hubungan antara pemerintah pusat dan daerah. Perubahan (amandemen) terhadap ketentuan Pasal 18, Pasal 18A, Pasal 18B UUD 1945 (amandemen), memberikan arah dan format baru dalam kaitan dengan prinsip-prinsip penyelenggaraan pemerintahan di daerah. Perubahan terhadap Pasal 18 UUD 1945 juga dimaksudkan untuk lebih memperjelas pembagian daerah dalam Negara Kesatuan Republik Indonesia, dimana istilah "dibagi atas" (bukan "terdiri atas") sebagaimana dimaksud dalam Pasal 18 ayat (1) UUD $1945^{2}$. Berkenaan dengan prinip-prinsip sebagaimana dimaksudkan dalam ketentuan Pasal 18, Pasal 18A, Pasal 18B UUD NRI Tahun 1945 tersebut diatas, Phlipus M. Hadjon ${ }^{3}$, menyatakan bahwa :

“Pasal 18 Mengandung” Prinsip pembagian daerah yang bersifat hirarkis (ayat 1);

1 Asgar, Sukitman,. (2018). "Analisis Yuridis Pasal 18 UUD Tahun 1945 Junto UU Nomor 23 Tahun 2014 Tentang Pemerintahan Daerah”, Jurnal HIBUALAMO, 2 (1): 58-68, h. 61

2 Huda, Ni'matul. (2007), Pengawasan Pusat Terhadap Daerah Dalam Penyelenggaraan Pemerintahan Daerah, FH UII Press, h. 50. Lihat juga, Said, Abdul Rauf Alauddin. (2015), "Pembagian Kewenangan Pemerintahaan Pusat - Pemerintahan Daerah Dalam Otonomi Seluas Luasnya Menurut UUD1945", Fiat Justisia: Jurnal Ilmu Hukum, 9 (4): 577-602, h.579

3 Hadjon, Philipus M. (2004), Kedudukan Undang-Undang Pemerintahan Daerah Dalam Sistem Pemerintahan, disampaikan dalam Seminar Sistem Pemerintahan Indonesia Pasca Amandemen UUD 1945 diselenggarakan oleh Badan Pembinaan Hukum Nasional Departemen Kehakiman dan Hak Asasi Manusia R.I. Bekerjasama dengan Fakultas Hukum Universitas Airlangga dan Kantor Wilayah Departemen Kehakiman dan Hak Asasi Manusia Provinsi Jawa Timur, Surabaya, h. 1-3. 
Prinsip otonomi dan tugas pembantuan (ayat 2); Prinsip demokrasi (ayat 3 dan 4); dan Prinsip otonomi seluas-luasnya (ayat 5). Pasal 18A Merupakan prinsip hubungan antara pemerintah pusat dan pemerintah daerah yang meliputi : Hubungan wewenang (ayat 1) dan Hubungan keuangan, pelayanan umum, pemanfaatan sumber daya (ayat 2). Pasal 18B Mengandung prinsip pengakuan pemerintah daerah yang bersifat khusus atau yang bersifat istimewa; dan prinsip pengakuan eksistensi dan hak-hak tradisional masyarakat adat"

Otonomi daerah sebaiknya luwes, kenyal, dengan melihat kemampuan inisiatif dan kondisi spesifik masing-masing daerah. Negara Indonesia sebagai Negara Kesatuan yang berbentuk Republik melandasi pelaksanaan pemerintahan di daerah pada asas desentralisasi. Kaidah asas ini melahirkan makna otonom, dengan substansi pe ${ }^{4}$ nyerahan (overdragen) kewenangan atau urusan pemerintahan kepada daerah. Makna yang terkandung dalam asas desentralisasi bahwa penyelenggaraan urusan umum pemerintahan oleh pemerintah daerah terkait otonomi mengatur dan otonomi mengurus urusan pemerintahan. Penyelenggaraan desentralisasi mensyaratkan pembagian urusan pemerintahan antara Pemerintah dengan pemerintahan daerah. Dalam konteks yang demikian, menurut Bagir Manan ${ }^{5}$, bahwa :

"Prinsip daerah mengatur dan mengurus sendiri urusan pemerintahan menurut asas otonomi dan tugas pembantuan (Pasal 18 ayat 2). Ketentuan ini menegaskan bahwa pemerintahan daerah adalah suatu pemerintahan otonomi dalam Negara Kesatuan Republik Indonesia. Dalam pemerintahan daerah hanya ada pemerintahan otonomi (termasuk tugas pembantuan). Dengan perkataan lain, ketentuan ini hanya mengatur mengenai otonomi. Prinsip baru dalam Pasal 18 baru, lebih sesuai dengan gagasan daerah membentuk pemerintahan daerah sebagai satuan pemerintahan mandiri di daerah yang demokratis"

Dengan demikian, jelas bahwa penyerahan urusan pemerintahan oleh Pusat kepada Daerah sebagai urusan rumah tangga daerah merupakan kosekuensi dianutnya prinsip desentralisasi sebagaimana diatur dalam Pasal 18 ayat (2) UUD NRI Tahun 1945. Hakekat dari negara kesatuan adalah negara yang kedaulatannya tidak terbagi, atau dengan kata lain, negara yang kekuasaan pemerintah pusatnya tidak terbatas karena konstitusi negara kesatuan tidak mengakui adanya badan pembuat undang-undang selain badan pembuat undangundang pusat.

Dalam negara kesatuan, pemeritah pusatlah yang memegang kedaulatan tertinggi negara. Sejalan dengan hal tersebut, C. F. Strong ${ }^{6}$ mengemukakan esensi atau hakekat negara kesatuan yakni "the essence of aunitary state is that the sovereignty is undivided, in other word, that the powers of the central government are unrestricted for the constitution of a unitary state does not admint of any other law-making body than the central one". Selaras dengan tujuan otonomi daerah penyelenggaraan pemerintah daerah diarahkan untuk mempercepat terwujudnya kesejahteraan masyarakat melalui peningkatan pelayanan, pemberdayaan, dan peran serta masyarakat, serta peningkatan daya saing daerah dengan memperhatikan prinsip demokrasi, pemerataan, keadilan, dan kekhasan suatu daerah dalam sistem Negara Kesatuan Republik Indonesia .

Urusan yang diserahkan kepada daerah disertai dengan sumber pendanaan, pengalihan

4 Matitaputty, Merlien I. (2012). "Desentralisasi dan Hubungan Pemerintah Pusat dan Daerah di Indonesia (Problem dan Tantangan)", SASI, 18 (1): 21-28, h. 27

5 Manan, Bagir. (2004), Menyongsong Fajar Otonomi Daerah, Yogyakarta: Pusat Studi Hukum Faluktas Hukum Universitas Islam Indonesia, h. 8

6 Strong, C. F. (1960). Modern Political Constitutions an Introduction to the Comparative Study of their History and Existing Form, London: Fith Printed, Sidwick \& Jackson Limited, h. 80 
sarana dan prasarana, serta kepegawaian sesuai dengan urusan yang didesentralisasikan. Sedangkan urusan pemerintahan yang dilimpahkan kepada Gubernur disertai dengan pendanaan sesuai dengan urusan yang didekonsentrasikan ${ }^{7}$, dalam pelaksanaan urusan pemerintahan oleh daerah otonom, daerah diberikan kewenangan dalam mengatur dan mengurus sendiri urusan rumah tangganya baik melalui dekosentrasi, desentralisasi maupun tugas pembantuan. Dalam hubungan tersebut, Irfan Ridwan Maksum ${ }^{8}$, mengemukakan bahwa:

"Pembagian urusan Pemerintahan antara Pemerintah Pusat dan daerah otonom tidak dapat dipisahkan dengan pengembangan instrumen desentralisasi dari sebuah negara. Untuk menelusurinya bahkan terlebih dahulu perlu mengetahui apakah bentuk negara yang dikembangkan oleh sebuah bangsa Kesatuan atau Federal. Jika Kesatuan, maka desentralisasi yang dikembangkan dilakukan oleh Pemerintah Pusat di tingkat nasional, sedangkan di Negara Federal, desentralisasi dilakukan oleh Pemerintah Negara Bagian. Di negara federal, seringkali UUD (konstitusi) Negara Federal mengatur umum saja keberadaan pemerintah daerah di negara tersebut seperti di Jerman, tetapi ada pula negara federal yang mengatur keberadaan pemerintah daerahnya di masing-masing UUD (konstitusi) Negara Bagian-nya, seperti di AS".

Berangkat dari penjelasan dan uraian tersebut diatas yang mendasari latar belakang penelitian ini, maka isu hukum yang dikedepankan adalah terkait dengan model penataan daerah dalam hubungan dengan model pembagian urusan pemerintahan yang berkarakter desentralistik. Secara konseptual esensi desentralisasi berkaitan dengan pola pembagian urusan pemerintahan sehingga konstruksi penataan kelembagaan daerah menjadi sangat penting untuk dilakukan pengkajian dan analisis terkait dengan model pembagian urusan pemerintahan daerah.

\section{B. METODE PENELITIAN}

Merujuk pada uraian latar belakang yang telah dikemukakan diatas, maka analisis terhadap isu hukum terkait dengan model pembagian urusan pemerintahan dilakukan dengan menggunakan metode penelitian hukum. Penelitian hukum itu sendiri merupakan proses untuk menemukan aturan hukum, prinsip-prinsip hukum, maupun doktrin-doktrin hukum guna menjawab isu hukum yang dihadapi. Penelitian ini, terutama mengkaji ketentuanketentuan hukum positif maupun asas-asas hukum. Selain itu, metode penelitian hukum bertujuan untuk mencari pemecahan atas isu hukum serta permasalahan yang timbul didalamnya, sehingga hasil yang akan dicapai kemudian adalah memberikan preskripsi mengenai apa yang seyogyanya atas isu yang diajukan ${ }^{9}$

Pendalaman terhadap isu hukum terkait dengan model pembagian urusan pemerintahan dilakukan melalui pendekatan konseptual (conceptual approach) dan pendekatan perundang-undangan (statue approach) untuk memberikan kejasalan soal penafsiran hukum atas rumusan norma yang mengatur tentang pembagian urusan pemerintahan. Hal ini penting untuk menghindari kesesatan dalam melakukan penalaran (Contradictio in termino) yang berimplikasi pada kesesatan (fallacy) serta penerapan hukum. Dalam pendekatan teori

7 Hasrul, Muh., (2017). "Penataan Hubungan Kelembagaan Antara Pemerintah Provinsi dengan Pemerintah Kabupaten/Kota", Perspektif, 22 (1): 1-20, h.7

8 Maksum, Irfan Ridwan. (2009). Perbandingan Sistem Pembagian Urusan Pemerintahan Antara Pemerintah Pusat Dan Daerah Otonom,_Laporan DSF Bank Dunia, h.10-12

${ }^{9}$ Hadjon, Philipus M. (1997). Pengkajian Ilmu Hukum, Makalah, Pelatihan Metode Penelitian Hukum Normatif, Surabaya: Universitas Airlangga, h. 20. Lihat juga Marzuki, Peter M. (2005). Penelitian Hukum Jakarta: Kencana Prenada Media Group, h. 35. 
hukum, kesalahan dalam merumuskan konsep mengakibatkan kesalahan dalam mengambil kesimpulan. Dalam logika dkenal rumus "Ex Falso Quo Libet”. Artinya, dari yang palsu (salah) seenaknya bisa benar bisa salah. Faktor kebutulan berperan dalam hukum bisa terjadi kesewenang-wenangan dan bahkan muncul penyalagunaan wewenang. Selain itu juga, kejelasan konsep sangat berpengaruh dalam kerangka legal problem solving sebagaimana dikenal dalam "Prinsip Contextualism" dalam intepretasi sebagaimana dikemukakan oleh Ian Mcleod ${ }^{10}$.

\section{PEMBAHASAN}

Sebagai akibat dari perkembangan ketatanegaraan dan semakin kompleksnya urusan pemerintahan, maka ruang lingkup urusan pemerintahan tidak lagi dapat diidentifikasikan secara kuantitatif namun sebaliknya urusan pemerintahan tersebut senantiasa akan selalu dinamis dan terbuka, serta dipengaruhi pula oleh konsep negara kesejahteraan. Dianutnya konsep negara kesejahteraan (welfarestate) telah membawa perubahan pada ruang lingkup dan isi wewenang, tugas dan tanggung jawab pemerintah baik kuantitatif maupun kualitatif, dimana tugas-tugas baru bertambah dan tugas-tugas lam makin berkembang ${ }^{11}$.

Sebagaimana diamanatkan UUD NRI Tahun 1945, penyelenggaraan negara dalam penyelenggaraan kekuasaan pemerintahan sepenuhnya menjadi kewenangan pemerintah pusat, dimana dalam ketentuan Pasal 4 ayat (1) UUD NRI Tahun 1945 kekuasaan pemerintahan negara berada ditangan Presiden. Demikian juga dalam Pasal 5 ayat (1) Undang Undang Nomor 23 Tahun 2014, disebutkan pula bahwa "Presiden Republik Indonesia memegang kekuasaan pemerintahan sesuai dengan Undang-Undang Dasar Negara Republik Indonesia Tahun 1945". Apabila diperhatikan kekuasaan pemerintahan sebagaimana dimaksud dalam ketentuan Pasal 5 ayat (1) Undang Undang Nomor 23 Tahun 2014 tidaklah berbeda dengan ketentuan sebagaimana dimaksud dalam Pasal 19 ayat (1) Undang Undang Nomor 32 Tahun 2004. Lebih lanjut dalam ayat (2) disebutkan bahwa "Kekuasaan Pemerintahan sebagaimana dimaksud pada ayat (1) diuraikan dalam berbagai urusan pemerintahan. Kemudian dalam Penjelasan Umum angka (3) menyebutkan bahwa:

"Sebagaimana diamanatkan oleh Undang-Undang Dasar Negara Republik Indonesia Tahun 1945,terdapat Urusan Pemerintahan yang sepenuhnya menjadi kewenangan Pemerintah Pusat yang dikenal dengan istilah urusan pemerintahan absolut dan ada urusan pemerintahan konkuren. Urusan pemerintahan konkuren terdiri atas Urusan Pemerintahan Wajib dan Urusan Pemerintahan Pilihan yang dibagi antara Pemerintah Pusat, Daerah provinsi, dan Daerah kabupaten/kota. Urusan Pemerintahan Wajib dibagi dalam Urusan Pemerintahan Wajib yang terkait Pelayanan Dasar dan Urusan Pemerintahan Wajib yang tidak terkait Pelayanan Dasar......"

Mengenai urusan pemerintahan tersebut diatas, dalam hubungannya dengan konsep pembagian kekuasaan secara vertikal hal tersebut secara formal merupakan kosekuensi yuridis dari ketentuan Pasal 1 ayat (1), Pasal 4 ayat (1), dan Pasal 18 ayat (1) UUD NRI Tahun 1945. Namun demikian, terdapat beberapa hal (sebab) yang melatar belakangi konsep (ide) dianutnya pembagian kekuasaan secara vertikal sehingga memungkinkan sebagian kekuasaan ataupun wewenang pemerintah pusat atas kuasa undang-undang diserahkan kepada satuan pemerintahan yang lebih rendah.

${ }^{10}$ Hadjon, Philipus M. dan Sridjatmiati, Tatiek. (2005). Argumentasi Hukum, Yogyakarta: Gadja Mada University Press, h. 44

11 Manan, Bagir. (1994). Hubungan Antara Pusat Dan Daerah Menurut UUD 1945, Jakarta: Pustaka Sinar Harapan, h. 18. 
Konsep pembagian kekuasaaan secara vertikal yang didasarkan pada asas desentralisasi, melahirkan pemerintahan daerah yang otonom. Pola pembagian kekuasaan tersebut tentunya menjadi dasar dalam hubungan antara pemerintah pusat dan daerah. Pemerintahan daerah menyelenggarakan urusan pemerintahan yang menjadi kewenangannya, kecuali urusan pemerintahan yang menjadi urusan Pemerintah. Dalam menyelenggarakan urusan pemerintahan yang menjadi kewenangan daerah tersebut, pemerintahan daerah menjalankan otonomi seluas-luasnya untuk mengatur dan mengurus sendiri urusan pemerintahan berdasarkan asas otonomi dan tugas pembantuan. Dalam konsep pelaksanaan wewenang pemerintahan, dalam kepustakaan hukum tata negara/hukum administrasi, badan atau pejabat tata usaha negara itu memperoleh wewenang untuk melaksanakan pemerintahan dapat dilihat dari sudut prosedur dan substansi pemberian wewenang yang bertumpuh pada 3 (tiga) landasan utama yakni (1) asas negara hukum; (2) asas demokrasi; dan (3) asas instrumental ${ }^{12}$.

Pada bagian lain, penyelenggaraan pemerintahan daerah juga terhadap perbedaan dalam hal ini berkaitan dengan asas penyelenggaraan pemerintahan baik yang diatur dalam UUD NRI Tahun 1945 maupun diatur dalam undang-undang tentang pemerintahan daerah. UUD NRI Tahun 1945, tidak mengelompokan desentralisasi dan dekosentrasi sebagai asas penyelenggaraan pemerintahan daerah, melainkan asas otonomi dan tugas pembantuan. Hal ini dapat dilihat pada ketentuan Pasal 18 ayat (2) yang menyatakan bahwa "Pemerintahan daerah provinsi, daerah kabupaten, dan kota mengatur dan mengurus sendiri urusan pemerintahan menurut asas otonomi dan tugas pembantuan". Pengaturan yang sama dapat kita lihat dalam ketentuan Pasal 2 ayat (2) UU Nomor 32 Tahun 2004 yang menyatakan bahwa "Pemerintahan daerah sebagaimana dimaksud pada ayat (1) mengatur dan mengurus sendiri urusan pemerintahan menurut asas otonomi dan tugas pembatuan. Namun demikian hal tersebut berbeda pengaturannya dalam UU Nomor 23 Tahun 2014, dimana dalam ketentuan Pasal 5 ayat (4) disebutkan bahwa " Penyelenggaraan Urusan Pemerintahan di daerah yang tercantum dalam ayat (2) diselenggarakan berdasarkan asas Desentralisasi, Dekonsentrasi, dan Tugas Pembantuan. Lebih lanjut konstruksi pembagian urusan pemerintahan berdasarkan Undang Undang Nomor 32 Tahun 2004 dan Undang Undang Nomor 23 Tahun 2014, dapat dilihat pada tabel dibawah ini :

Tabel 1. Perbandingan Pembagian Urusan Pemerintahan Bersadasarkan UU Nomor 32 Tahun 2004 dan UU Nomor 23 Tahun 2014

\begin{tabular}{lll}
\hline UU Nomor 32 Tahun 2004 & UU Nomor 23 Tahun 2014 \\
\hline $\begin{array}{l}\text { 1. Urusan pemerintahan terdiri dari } \\
\text { urusan yang bersifat absolut dan } \\
\text { urusan yang bersifat konkurent }\end{array}$ & $\begin{array}{l}\text { 1. Urusan pemerintahan terdiri dari } \\
\text { urusan yang bersifat absolut, urusan } \\
\text { pemerintahan umum, dan urusan } \\
\text { yang bersifat konkurent }\end{array}$ \\
\hline $\begin{array}{l}\text { 2. Urusan pemerintahan absolut, } \\
\text { meliputi (a) Pertahanan; } \quad \text { (b) }\end{array}$ & $\begin{array}{l}\text { 2. Urusan pemerintahan absolut, } \\
\text { meliputi }\end{array}$ \\
$\begin{array}{ll}\text { Keamanan; (c) Agama; (d) Yustisi; } \\
\text { (e) Polugri; dan (f) Agama }\end{array}$ & $\begin{array}{l}\text { Keamanan; (c) Agama; (d) Yustisi; } \\
\text { (e) Polugri; dan (f) Agama }\end{array}$ \\
\hline $\begin{array}{l}\text { 3. Urusan konkurent, terdiri dari urusan } \\
\text { wajib dan urusan pilihan }\end{array}$ & $\begin{array}{l}\text { 3. Urusan konkurent, terdiri dari urusan } \\
\text { wajib (pelayanan dasar dan } \\
\text { pelayanan non dasar) dan urusan } \\
\text { pilihan }\end{array}$ \\
\hline
\end{tabular}

12 Aridhayandi, M. Rendi. (2018). "Peran Pemerintah Daerah Dalam Pelaksanaan Pemerintahan Yang Baik (Good Governance) Dibidang Pembinan dan Pengawasan Indikasi Geografis", Jurnal Hukum \& Pembangunan, 48 (4): 883-902, h.888. 
4. Urusan pemerintahan umum, yakni urusan pemerintah pusat yang dilimpahkan pelaksanaannya kepada Gubernur dan Bupati / Walikota diwilayahnya masing-masing; misalnya urusan menjaga 4 (empat) konsensus dasar

Memperhatikan asas penyelenggaraan pemerintahan sebagaimana dikemukakan diatas, apabila dihubungkan dengan teori perundang-undangan (asas perundang-undangan) akan menimbulkan kosekuensi hukum tersendiri oleh karena itu diperlukan kajian dari pendekatan hukum tata negara utamnya berkaitan dengan konsep dan pengaturannya. Pada bagian ini, kajian dan analis terhadap permsalahan tersebut diatas meliputi (1) pembagian urusan pemerintahan; dan (2) model pembagian urusan pemerintahan yang berkarakter desentralistik.

\section{Pembagian Urusan Kepemerintahan}

Sebagaimana telah dikemukakan sebelumnya diatas, bahwa pembagian kekuasaan secara horizontal dan pembagian kekuasaan secara vertikal, dalam konsep negara kesatuan memberikan kosekuensi penyerahan urusan pemerintahan. Salah satu permasalahan yang mendasar adalah pendelegasian kewenangan kepada pemerintah daerah serta seberapa besar kewenangan yang dilimpahkan atau diserahkan kepada daerah dalam mengurus dan mengatur pelaksanaan pemerintahan di daerah.

Secara umum pembagian urusan-urusan kepemeritahan dapat digambarkan sebagai berikut dibawah ini:

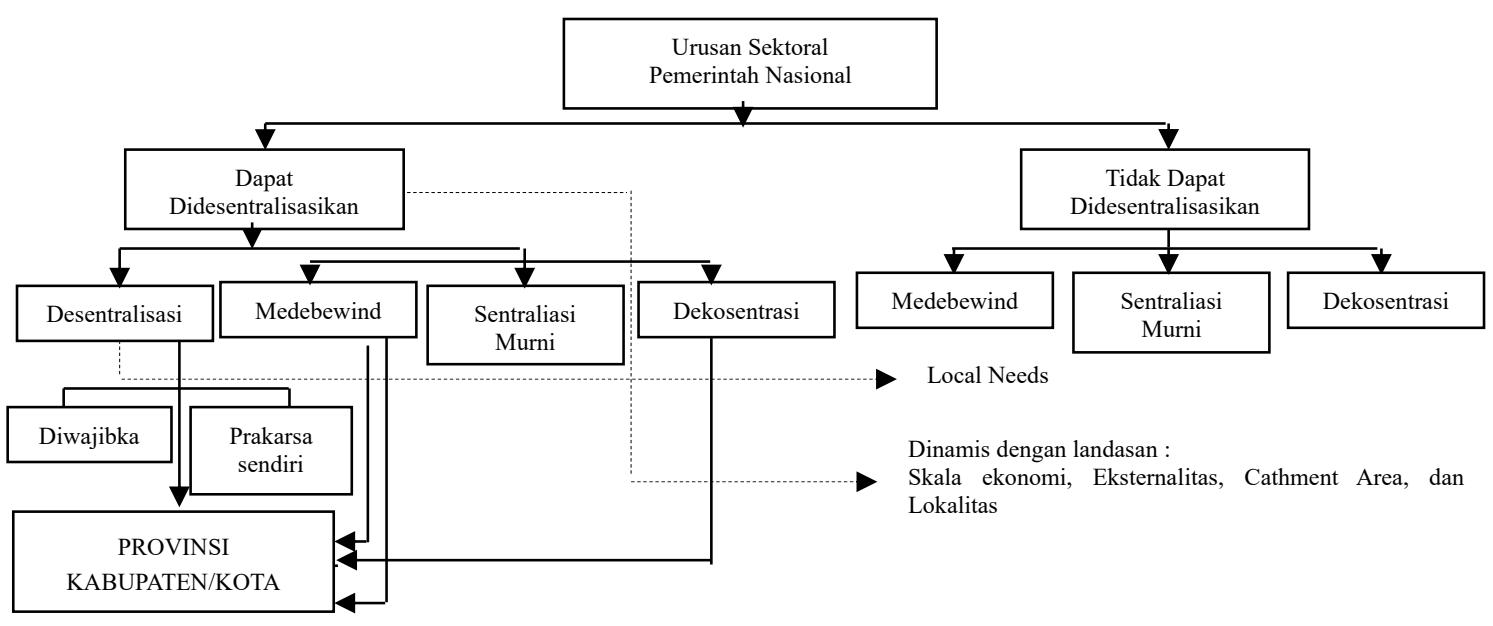

Gambar 1. Bagan Pembagian Urusan-Urusan Kepemerintahan

Undang Undang Nomor 23 Tahun 2014 mengkonstruksikan klasifikasi urusan pemerintahan sebagaimana disebutkan dalam Pasal 9 ayat (1) sampai dengan ayat (5). Sedangkan urusan pemerintahan absolut lebih lanjut dalam ketentuan Pasal 10 ayat (1) dan ayat (2) Undang Undang Nomor 23 Tahun 2014. Selanjutnya mengenai urusan pemerintahan konkuren, lebih lanjut dalam ketentuan Pasal 11 ayat (1) sampai ayat (3) Undang Undang Nomor 23 Tahun 2014. Apabila diperhatikan secara cermat, pola pembagian urusan pemerintahan sebagaimana dimaksudkan dalam ketentuan Pasal 9 ayat (2) dan Pasal 10 ayat 
(1) Undang Undang Nomor 23 Tahun 2014 adalah sama dengan pola pembagian urusan pemerintahan sebagaimana dimaksud dalam Pasal 10 ayat (1) dan ayat (3) Undang Undang Nomor 32 Tahun 2004. Pembagian wewenang dalam Undang Undang Nomor 32 Tahun 2004 dikembangkan melalui kriteria (1) Eksternalitas; (2) Akuntabilitas; dan (3) Efisiensi. Sementara itu, dalam Undang Undang Nomor 23 Tahun 2014 sebagaimana ditegaskan dalam ketentuan Pasal 13, disebutkan bahwa "Pembagian urusan pemerintahan konkuren antara Pemerintah Pusat dan Daerah provinsi serta Daerah kabupaten/kota sebagaimana dimaksud dalam Pasal 9 ayat (3) didasarkan pada prinsip akuntabilitas, efisiensi, dan eksternalitas, serta kepentingan strategis nasional.

Pola pembagian urusan pemerintahan sebagaimana dikemukakan diatas, dalam pelaksanaannya seringkali menimbulkan permasalahan (konflik) dan kefakuman dalam proses pemerintahan. Sebaliknya apabila ditata secara baik akan memberikan sinergi dan memberikan arah bagi penyelenggaraan pemerintahan yang lebih baik dan berkualitas. Hal ini didasarkan pada suatu realitas secara empirik banyak terjadi tumpang tindih (overlapping) kewenangan yang kalau dibiarkan dapat menimbulkan friksi dan ketegangan antar tingkatan pemerintahan berkaitan dengan kewenangan daerah. Tiga jenis tumpang tindih tersebut yakni (a) tumpang tindih antara kewenangan Pusat dan Daerah; (b) tumpang tindih antara kewenangan Propinsi dengan Kabupaten/ Kota; dan (c) tumpang tindih antar kewenangan Kabupaten/ kota itu sendiri.

Penyebab utama dari berbagai tumpang tindih tersebut adalah tidak sinkronnya antar berbagai peraturan perundangan yang mengatur masing-masing kewenangan tersebut baik di tingkat undang-undang (UU), Peraturan Pemerintah (PP), maupun di tingkat Keputusan Menteri (Kepmen) terkait dengan kewenangan tersebut. Salah satunya adalah potensi konflik dalam kaitan dengan wewenang pengelolaan sumber daya alam (SDA) di wilayah laut yang berimplikasi pada undang-undang sektoral lainnya yang berkaitan baik secara langsung maupun tidak langsung dengan wewenang pengelolaan SDA oleh daerah.

\section{Model Pembagian Urusan Pemerintahan Yang Berkarakter Desentralistik}

Pendekatan politik hukum pelaksanaan pemerintahan daerah sebagaimana dimaksudkan dalam ketentuan Pasal 1 ayat (1), Pasal 4 ayat (1), dan Pasal 18 UUD NRI Tahun 1945, secara tegas menghendaki konsep desentralisasi dalam negara kesatuan. Dengan demikian, dalam suatu negara kesatuan pada hakekatnya semua urusan pemerintahan berada pada pemerintah psuat, namun demikian urusan pemerintahan tersebut dapat diserahkan atau didelegasikan kepada satuan pemerintahan yang lebih rendah. Penyerahan urusan tersebut memberikan kosekuensi pula diadakannya pembagian wilayah negara. Hal ini dapat kita lihat pada ketentuan Pasal 18 ayat (1) UUD NRI Tahun 1945, dan juga ditegaskan lebih lanjut dalam ketentuan Pasal 5 Undang Undang Nomor 23 Tahun 2014.

Dalam ketentuan Pasal 18 ayat (1) UUD NRI Tahun 1945, menyebutkan bahwa "Negara Kesatuan Republik Indonesia dibagi atas daerah-daerah provinsi dan daerah provinsi itu dibagi atas kabupaten dan kota, yang tiap-tiap provinsi, kabupaten, dan kota itu mempunyai pemerintahan daerah, yang diatur dengan undang-undang" Sedangkan Ketentuan Pasal 5 ayat (1) Undang Undang Nomor 23 Tahun 2014, menyebutkan bahwa "Negara Kesatuan Republik Indonesia dibagi atas Daerah provinsi dan Daerah provinsi itu dibagi atas Daerah kabupaten dan kota". Selanjutnya dalam Ayat (2) disebutkan bahwa "Daerah kabupaten/kota dibagi atas Kecamatan dan Kecamatan dibagi atas kelurahan dan/atau Desa"

Secara konseptual desentralisasi dalam pelaksanaan pemerintahan daerah di Indonesia dalam ketentuan Pasal 1 angka (8) Undang Undang Nomor 23 Tahun 2014, dirumusakan sebagai penyerahan urusan pemerintahan oleh pemerintah pusat kepada daerah otonom

$$
564 \text { |S A S I Vo1. } 26 \text { No.4, Oktober-Desember } 2020
$$


berdasarkan asas otonomi. Urusan Pemerintahan itu sendiri dalam rumusan ketentuan Pasal 1 angka (5) Undang Undang Nomor 23 Tahun 2014, adalah kekuasaan pemerintahan yang menjadi kewenangan Presiden yang pelaksanaannya dilakukan oleh kementerian negara dan penyelenggara Pemerintahan Daerah untuk melindungi, melayani, memberdayakan, dan menyejahterakan masyarakat ${ }^{13}$.

Urusan pemerintahan dirumuskan oleh Hadjon, adalah sebagai berikut, yakni : $\mathrm{B}=\mathrm{KN}$ - $(\mathrm{rg}+\mathrm{rh})$. Urusan pemerintahan (bestuu;r; B), adalah semua kekuasaaan atau kegiatan negara $(\mathrm{KN})$ dikurangi pembuatan undang-undang (regelgeving; rg) dan peradilan (rechtsspaak; rh) ${ }^{14}$. Konsep desentralisasi sebagaimana dimaksudkan dalam Undang Undang Nomor 23 Tahun 2014 tersebut diatas dimaknai dalam kaitan dengan "penyerahan urusan pemerintahan”. Hal ini berbeda dengan Undang Undang Nomor 32 Tahun 2004 yang merumuskan konsep desentralisasi sebagai "pelimpahan wewenang, dimana dalam ketentuan Pasal 1 angka (7) Undang Undang Nomor 32 Tahun 2004, menyebutkan bahwa "Desentralisasi adalah penyerahan wewenang pemerintahan oleh Pemerintah kepada daerah otonom untuk mengatur dan mengurus urusan pemerintahan dalam sistem Negara Kesatuan Republik Indonesia"

Penyelenggaraan desentralisasi mensyaratkan pembagian urusan pemerintahan antara Pemerintah dengan pemerintahan daerah. Urusan pemerintahan terdiri dari urusan pemerintahan yang sepenuhnya menjadi kewenangan pemerintah dan urusan pemerintahan yang dikelola secara bersama antar tingkatan dan susunan pemerintahan. Dalam Penjelasan Umum Peraturan Pemerintah Nomor 38 Tahun 2008, dijelaskan bahwa Urusan pemerintahan yang dapat dikelola secara bersama antar tingkatan dan susunan pemerintahan atau konkuren adalah urusan-urusan pemerintahan selain urusan pemerintahan yang sepenuhnya menjadi urusan Pemerintah. Dengan demikian dalam setiap bidang urusan pemerintahan yang bersifat konkuren senantiasa terdapat bagian urusan yang menjadi kewenangan Pemerintah, pemerintahan daerah provinsi, dan pemerintahan daerah kabupaten/kota

Dengan demikian, dalam setiap bidang urusan pemerintahan yang bersifat konkuren senantiasa terdapat urusan yang menjadi kewenangan pemerintah, pemerintah daerah provinsi, pemerintah daerah kabupaten/kota. Urusan pemerintahan yang sepenuhnya menjadi kewenangan pemerintah adalah urusan dalam bidang politik luar negeri, pertahanan, keamanan, moneter dan fiskal nasional, yustisi, dan agama, sebagaimana dimaksud dalam ketentuan Pasal 2 ayat (1) dan ayat (2) Peraturan Pemerintah Nomor 38 Tahun 2007. Urusan yang menjadi kewenangan pemerintah daerah (Provinsi dan Kabupaten/Kota) terdiri dari urusan wajib dan urusan pilihan sebagaimna dimaksud dalam ketentuan Pasal 11 dan Pasal 12 Undang-Undang Nomor 23 Tahun 2014

Pola pembagian urusan pemerintahan dalam Undang Undang Nomor 23 Tahun 2014, model pembagian urusan pemerintahan terjadi pergeseran berdasarkan murni "ultra vires doctrine" sehingga tidak "compatible" dengan sistem Jerman, sehingga berakibat terhadap penerapan kebijakan desentralisasi. Pembagian urusan pemerintahan antara pusat dan daerah pada undang-undang ini semakin condong pada sistem otonomi materil. Selain condong pada sistem otonomi materil, status sebagai perwakilan pemerintah pusat yang pada undangundang sebelumnya dalam Undang Undang Nomor 32 Tahun 2004 hanya diemban oleh

13 Aritonang, Dinoroy Marganda. (2016). "Pola Distribusi Urusan Pemerintahan Daerah Pasca Berlakunya Undang Undang Nomor 23 Tahun 2014 Tentang Pemerintahan Daerah”, Jurnal Legislasi Indonesia, 13 (1): 41-41, h.42-43

14 Hadjon, Phlipus M et al. (1993). Pengantar Hukum Administrasi Indonesia, Yogyakarta: Gadja Mada University Press, h. 4. 
Gubernur, kini juga diemban oleh Kepala Daerah Kabupaten/Kota. Artinya, setiap satuan pemerintahan, baik pada tingkat provinsi maupun tingkat Kabupaten/Kota, merupakan objek dekonsentrasi. Kondisi ini mengakibatkan dipertanyakannya politik hukum otonomi daerah yang terkandung di dalam Undang Undang 23 Tahun 2014 yang seolah semakin mengarah pada sistem sentralistik. Padahal, amanat UUD NRI Tahun 1945 pada Pasal 18 adalah menjalankan otonomi seluasluasnya dalam penyelenggaraan pemerintahan daerah.

Berangkat dari apa yang diuraikan diatas, dapat dikatakan bahwa pola pengaturan urusan pemerintahan yang berkarakter desentraliktik pada hakekatnya bertumpuh pada pembagian kekuasaan (kewenangan) dan siapa yang berwenang mengurus dan mengatur urusan tersebut. Selanjutnya, berkaitan dengan pendelegasian kewenangan kepada pemerintah daerah serta seberapa besar kewenangan yang dilimpahkan atau diserahkan kepada daerah dalam mengurus dan mengatur pelaksanaan pemerintahan di daerah.Dengan kata lain, pola pengaturan terhadap urusan pemerintahan dalam konsep desentralisasi dilihat dari hubungan pusat dan daerah yang mengacu pada UUD NRI Tahun 1945, tidak dimaknai secara simetris (seragam) namun dapat berbeda-beda antara satu daerah dengan daerah yang lain (asimetris) sesuai dengan karaterisk wilayah dan potensi daerah (kekhususan) dalam kerangka NKRI.

Secara teroritik ada beberapa cara (metode) dalam menentukan pembagian/penyerahan urusan pemerintahan kepada Pemerintah Daerah. Pertama, cara yang menganut kepada ajaran penyerahan formil (Formele Huishoudingsleer). Gadjong Agussalim Andi ${ }^{15}$., mengemukakan bahwa:

"Dalam model ini, kewenangan/urusan tidak diperinci secana normatif, dalam arti tidak dtetapkan satu per satu, melainkan ditentukan dalam suatu "rumusan umum". Dalam model atau cara ini, hanya ditentukan prinsip-prinsipnya saja, batasnya tidak ditentukan secara a priori, tergantung kepada keadaan, waktu, dan tempat. Pembagian kewenangan/urusan melalui model ini, dapat lebih memberikan keleluasaan kepada untuk mengambil prakarsa, memilih alternatif, dan mengambil keputusan sesaui dengan kepentingan daerah, sepanjang tidak atau belum diatur dengan Undang-undang atau peratran yang lebih tinggi. Model ini sering juga disebut sebagai "General Competence" (Open end arrangement). Kedua, model atau ajaran yang disebut"Ajaran Kerumahtangaan Materiil" (Materiele Huishoudingsleer"). Disini terdapat pembagian kewenangan/urusan yang berbeda sifatnya diantara tingkat-tingkat pemerintahan"

Secara normatif kewenangan/urusan daerah diperinci satu per satu dengan tegas dan ditentukan dalam undang-undang pembentukannnya. Dalam hal ini, Ari Dwipayana ${ }^{16}$, mengemukakan bahwa:

"Model ini sering disebut juga model "Ultra Vires". Di antara tingkatan pemerintahan Pusat, Daerah Provinsi, dan Derah Kabupaten/Kota memiliki kewenangan yang sama dengan sifat dan proporsi yang berbeda (Ini berasal dari teori kontinental yang disebut "De drie kringensleer". Dalam model ini, sering terjadi duplikasi kewenangan antara tingkat-tingkat pemerintahanan, sering terjadi sharing ratio dalam membagi kewenangan membias keatas, sehingga terjadi "piramid terbalik". Kejumbuhan (overlapping) dan vacuum-pemerintahan juga sering tgerjadi, karena timbulnya tarikmenarik kepentingan (conflict of interest) atau sebaliknya saling mengela terhadap

15 Andi, Gadjong Agussalim. (2007), Pemerintahan Daerah-Kajian Politik dan Hukum, Jakarta: Ghalia Inodnesia, h. 54.

16 Suryanto. (2015). "Urusan Pemerintahan Daerah, Kemungkinan Problematika Implementasi Undang Undang Nomor 23 Tahun 2014”, Jurnal Desentralisasi, 13 (2): 133-146, h.142-144 
tugas (jurisdictie-positief dan jurisdictie negatief). Ketiga, model yang disebut "Ajaran Kerumah-tanggaan Rieel" "Riele Huishoudingsleer". Dalam model ini pada prinsipnya pembagian kewenangan/urusan didasarkan kepada faktor-faktor yang nyata (rieel) untuk mecapai keserasian antara tugas dan kemampuan/kekuatan Daerah".

Apabila dikaji lebih lanjut, disini yang menjadi pertimbangan adalah penyesuaian dengan "keanekaragaman" (heterogeneous) dari masing-masing daerah yang bersangkutan, guna menyesuaikan pelaksanaan otonomi daerah dengan keadaan daerah masing-masing, dimana keadaan khusus (local specific) sangat diutamakan. Karenanya, dalam model ini mengandung fleksibilitas, anpa mengurangi "kepastian", sehingga Daerah bebas berprakarsa, memperhatikan pemerataan dan keseimbangan laju pertumbuhan antar Daerah, sehingga "kesenjangan" (disparity) antar Daerah dapat dikurangi ${ }^{17}$.

Salah satu hal penting dalam kaitan dengan wewenang pengelolaan SDA di wilayah laut bagi daerah-daerah yang berkarakter kepulauan atau gugus pulau sebagaimana dimaksud dalam ketentuan Pasal 27, Pasal 28 dan Pasal 29. Namun demikian, dalam ketentuan Pasal 30 disebutkan bahwa "Ketentuan lebih lanjut mengenai kewenangan Daerah provinsi di laut sebagaimana dimaksud dalam Pasal 27 dan Daerah Provinsi yang Berciri Kepulauan sebagaimana dimaksud dalam Pasal 28 dan Pasal 29 diatur dengan peraturan pemerintah". Pada bagian ini, muncul pertanyaan, apakah konsep pembagian kewenangan bersifat regular (-simetris seragam) ataukah non regular (asimetris- tidak seragam)? Pertanyaan ini penting untuk dikedepankan karena kondisi Indonesia yang beragam (tidak simetris) dari sisi konteks sejarah, sosi-kultural, ekonomi dan politik. Apakah keragaman tersebut dijawab dengan rumus yang simetris ataukah asimetris. Kalau simetris maka konsep pembagian kewenangan diterapkan seragam di semua daerah. Apalabila konsep pembagian kewenangan adalah asimetris maka dimungkinkan perbedaan cara pembagian kewenangan antar daerah, atau bahkan secara teoritik sudah dikenal konsep desentralisasi teritorial dan desentralisasi fungsional

Terhadap hal tersebut diatas, terdapat beberapa permasalahan yang muncul berkenaan dengan konsep pola pembagian urusan pemerintahan yakni Pertama, dalam kaitan dengan konsep kekuasaaan pemerintahan, Presiden Republik Indonesia memegang kekuasaan pemerintahan menurut UUD dengan Pasal 18 (1), (2) dan (5) dimana Pemerintahan daerah provinsi, daerah kabupaten mengatur dan mengurus sendiri pemerintahannya menurut asas otonomi dan tugas pembantuan. Pemerintahan daerah menjalankan otonomi seluas-luasnya kecuali urusan pemerintahan yang oleh undang-undang ditentukan sebagai urusan Pemerintah Pusat. Bagi yang menggunakan pasal 4 maka penyerahan urusan pemerintahan itu berasal dari kekuasaan ekekusetif (Presiden). Sedangkan yang menggunakan Pasal 18 menggunakan sumber kewenangan itu dari UUD NRI Tahun 1945 dan undang-undang.

Pembagian urusan pemerintahan konkuren antara Daerah provinsi dengan Daerah kabupaten/kota walaupun urusan pemerintahannya sama, perbedaannya akan nampak dari skala atau ruang lingkup Urusan Pemerintahan tersebut. Walaupun Daerah provinsi dan Daerah kabupaten/kota mempunyai Urusan Pemerintahan masing-masing yang sifatnya tidak hierarki, namun tetap akan terdapat hubungan antara Pemerintah Pusat, Daerah provinsi dan Daerah kabupaten/kota dalam pelaksanaannya dengan mengacu pada norma, standar, prosedur, dan kriteria (NSPK) yang dibuat oleh Pemerintah Pusat. Kewenangan pemerintah kabupaten / kota yang tersebar dalam urusan pemerintahan bersamaan yang menjadi sebelumnya kewenangan kabupaten / kota dipindahkan ke kewengan pemerintah provinsi. Transisi dari kewenangan seperti di bidang izin pertambangan dan pendidikan

17 Djambar., Nahar, M Yasin., Tavip, Muhammad. (2017). "Penyelenggaraan Urusan Pemerintahan Bidang Pertambangan Dalam Prespektif Otonomi Daerah”, eJurnal Katalogis, 5 (2): 26-35, h. 32 
menengah yang setara. Peralihan kewenangan tentu membawa konsekuensinya sendiri. Oleh karena itu menarik untuk dibaca menggunakan konsep dekonstruksi Derrida Jacques. ${ }^{18}$

Kewenangan pemerintah kabupaten / kota yang tersebar dalam urusan pemerintahan bersamaan yang menjadi sebelumnya kewenangan kabupaten / kota dipindahkan ke kewengan pemerintah provinsi. Transisi dari kewenangan seperti di bidang izin pertambangan dan pendidikan menengah yang setara. Peralihan kewenangan tentu membawa konsekuensinya sendiri. Oleh karena itu menarik untuk dibaca menggunakan konsep dekonstruksi Derrida Jacques

Konsep dekosentrasi dan tugas pembantuan seyogyanya dikembalikan kepada konsep sebagaimana diatur dalam Undang Undang Nomor 32 Tahun 2004. Pelembagaan konsep otonomi luas harus diperjelas lagi, terutama berkaitan dengan urusan wajib dan urusan pilihan. Urusan wajib meliputi urusan yang berkaitan dengan pelayanan dasar. Sedangkan urusan pilihan merupakan urusan yang secara nyata ada dan berpotensi dijalankan oleh daerah. Daerah juga dimungkinkan mengusulkan urusan pemerintahan menjadi kekhususannya, baik dalam skala provinsi atau wilayah. Oleh karena itu, diperlukan untuk mengembangkan desentralisasi fungsional yang diterapkan selama Hindia Belanda pada tahun 1920 dengan perkembangan Waterchappen mengenai perkembangan masalah perkotaan dan juga terkait dengan pengembangan distribusi masalah irigasi. Pengenalan desentralisasi fungsional membutuhkan perubahan pada Pasal 18 UUD NRI Tahun 1945.

Keuda, koherensi antara konsep desentralisasi melalui otonomi seluas-luasnya dengan regulasi sektoral? Pertanyaan ini penting karena konsep otonomi seluas-luasnya tereduksi oleh regulasi sektoral yang masih memberikan kewenangan pada departemen sektoral. Salah satu contohnya adalah potensi konflik kewenangan antara Undang Undang Otsus Aceh dan Papua dengan Undang Undang atau kebijakan Sektoral. Misalnya, Undang Undang Nomor 27/2007 dengan Undang Undang Nomor 11/2006. Undang-Undang Nomor 11 Tahun 2006 memberikan kewenangan yang besar bagi Pemerintah Aceh yang salah satunya mengelola sumber daya pesisir dan pulau-pulau kecilnya. Sedangkan Undang Undang Nomor 27 Tahun 2007 tentang Pengelolaan Pesisir dan Pulau-Pulau Kecil memberikan kewenangan yang besar bagi Menteri Kelautan dan Perikanan.

Ketiag, dalam praktek berbagai regulasi yang telah dikeluarkan tetap menimbulkan persoalan. Hal ini bisa dilihat dari masih terjadinya: (1) konflik kewenangan antara Pusat dengan Daerah, baik Provinsi maupun Kebupaten/ Kota; (2). Konflik kewenangan antara Provinsi ddengan Kabupaten/ Kota. (3), Konflik kewenangan antar kabupaten/ kota. (4). dapat terjadi tarik menarik wewenang dalam bidang urusan tertentu antara kabupaten/ kota dengan pengelola kawasan khusus. Meskipun terdapat kriteria pembagian urusan, namun tetap timbul persoalan karena regulasi tidak mendorong daerah otonom mengembangkan urusan pilihan berdasarkan kekhusus daerahnya. Dengan aturan pilihan yang ditentukan secara rigid maka daerah cenderung tidak memilih karena dianggap sebagai cost centre. Dalam hal ini Ari Dwipayana ${ }^{19}$, menyatakan bahwa:

"Kalaupun daerah ber-kreasi seringkali harus berhadapan dengan berbagai aturan Pemerintah pusat. Daerah juga kesulitan menentukan apakah suatu pengembangan urusan kelak di kemudian hari di luar yang ditentukan dalam lampiran termasuk dalam

18 Budiyono., Muhtadi., Firmansyah, Ade Arif. (2015). "Dekonstruksi Urusan Pemeritahan Konkuren Dalam Undang Undang Pemerintahan Daerah", Kanun: Jurnal Ilmu Hukum, 17 (3): 419-432, h.426-427

19 Dwipayana, Ari. Rekonseptualisasi Pembagian Kewenangan Antar Susunan Pemerintahan, h. 6. dalam Kertapradja, E. Koswara. (2007). Pokok-pokok Pikiran dalam Permasalahan Kedudukan Gubernur sebagai Wakil Pemerintah Pusat, Makalah dipersiapkan untuk bahan masukan pembahasan Revisi UU No. 32 Tahun 2004, Roundtable Meeting 
urusan Sisa atau Urusan Pilihan, dan dalam prakteknya, cara berpikir daerah menganggap semua urusan itu harus dijalankan, tanpa melihat dari sisi kebutuhan dan kemampuan. Tidak semua jenis urusan itu dibutuhkan dan tidak semua daerah mampu. Sistem yang dipakai belum membuka ruang bagi dinamika dalam penyelenggaraan urusan".

Sejalan dengan pemikiran tersebut diatas, apabila dikaitkan dengan kewenangan pembentukan Peraturan Daerah (Perda) sebagaimana dimaksud dalam Pasal 236 ayat (4) Undang Undang Nomor 23 Tahun 2014, yang menggunakan nomenklatur "muatan lokal" tanpa menjelaskan lebih lanjut mengenai makna "lokal" akan menimbulkan kekaburan terhadap makna lokal, apakah sama dengan "ciri khas" dalam Undang Undang Nomor 32 Tahun 2004. Hal ini juga akan berdampak pada parameter pengawasan Perda yang berciri khas daerah sebagaimana dimaksud dalam Pasal 250 ayat (1) Undang Undang Nomor 23 Tahun 2014. Kesulitas yang muncul adalah berhubungan dengan materi muatan Peraturan Daerah yang dibentuk tidak menjabarkan lebih lanjut ketentuan perundang-undangan yang lebih tinggi, tetapi materi muatan Peraturan Daerah tersebut merupakan ciri khas daerah, dapat dikatakan bertentangan dengan peraturan perundang-undangan yang lebih tinggi.

\section{P E N U T U P}

Berangkat dari uraian dan penjelasan yang telah dikemukakan sebelumnya terkait dengan pertama, pembagian urusan pemerintahan dan kedua terkait dengan model pembagian urusan pemerintahan yang berkarakter desentralistik, dapat disimpulkan bahwa pelaksanaan pemerintahan didaerah tidak saja memiliki justifikasi yuridis (normatif), namun juga memiliki landasan filosofis yang tercermin dalam konstitusi negara. oleh karena itu, penguatan otonomi dalam pelaksanaan desentralisasi haruslah mencerminkan keseimbangan antara penyerahan atau pelimpahan kewenangan disertai pula dengan penguatan terhadap pengawasan penyelenggaraan pemerintahan (pusat maupun daerah) dalam keutuhan kehidupan NKRI. Pengawasan ini menjadi sarana dalam menciptakan check and balances system penyelenggaraan pemerintahan. Pengaturan desentralisasi melalui penyelenggaraan otonomi daerah masih memiliki kecendrungan menggrogoti pendelegasian kewenangan ke daerah yang kecendrungannya penguatan aspek desentralisasi direduksi dengan pola pengaturan urusan pemerintahan dan kelembaan yang cendrung mengarah kepada resentralisasi. Hal ini menimbulkan penafsiran dan penerapan yang berbeda antara daerah yang cendrung menimbulkan konflik dan ego sektoral.

\section{DAFTAR PUSTAKA}

\section{Jurnal}

[1] Aritonang, Dinoroy Marganda. (2016). "Pola Distribusi Urusan Pemerintahan Daerah Pasca Berlakunya Undang Undang Nomor 23 Tahun 2014 Tentang Pemerintahan Daerah", Jurnal Legislasi Indonesia, 13 (1): 41-41.

[2] Asgar, Sukitman. (2018). "Analisis Yuridis Pasal 18 UUD Tahun 1945 Junto UU Nomor 23 Tahun 2014 Tentang Pemerintahan Daerah", Jurnal HIBUALAMO, 2 (1): 58-68.

[3] Aridhayandi, M. Rendi. (2018). "Peran Pemerintah Daerah Dalam Pelaksanaan Pemerintahan Yang Baik (Good Governance) Dibidang Pembinan dan Pengawasan Indikasi Geografis", Jurnal Hukum \& Pembangunan, 48 (4): 883-902.

[4] Budiyono.,Muhtadi., Firmansyah, Ade Arif. (2015). "Dekonstruksi Urusan Pemeritahan Konkuren Dalam Undang Undang Pemerintahan Daerah”, Kanun: Jurnal Ilmu Hukum, 17 (3): 419-432. 
[5] Djambar., Nahar, M Yasin., Tavip, Muhammad. (2017). "Penyelenggaraan Urusan Pemerintahan Bidang Pertambangan Dalam Prespektif Otonomi Daerah", eJurnal Katalogis, 5 (2): 26-35.

[6] Hasrul, Muh., (2017). "Penataan Hubungan Kelembagaan Antara Pemerintah Provinsi dengan Pemerintah Kabupaten/Kota", Perspektif, 22 (1): 1-20.

[7] Matitaputty, Merlien I. (2012). "Desentralisasi dan Hubungan Pemerintah Pusat dan Daerah di Indonesia (Problem dan Tantangan)", SASI, 18 (1): 21-28.

[8] Suryanto. (2015). "Urusan Pemerintahan Daerah, Kemungkinan Problematika Implementasi Undang Undang Nomor 23 Tahun 2014", Jurnal Desentralisasi, 13 (2): 133-146.

[9] Said, Abdul Rauf Alauddin. (2015), "Pembagian Kewenangan Pemerintahaan Pusat Pemerintahan Daerah Dalam Otonomi Seluas Luasnya Menurut UUD1945", Fiat Justisia: Jurnal Ilmu Hukum, 9 (4): 577-602.

\section{Buku}

[10] Andi, Gadjong Agussalim. (2007), Pemerintahan Daerah-Kajian Politik dan Hukum, Jakarta: Ghalia Inodnesia.

[11]Hadjon, Phlipus M et al. (1993). Pengantar Hukum Administrasi Indonesia, Yogyakarta: Gadja Mada University Press.

[12] Hadjon, Philipus M. dan Sridjatmiati, Tatiek. (2005). Argumentasi Hukum, Yogyakarta: Gadja Mada University Press.

[13]Huda, Ni'matul. (2007), Pengawasan Pusat Terhadap Daerah Dalam Penyelenggaraan Pemerintahan Daerah, FH UII Press.

[14] Marzuki, Peter M. (2005). Penelitian Hukum Jakarta: Kencana Prenada Media Group

[15] Strong, C. F. (1960). Modern Political Constitutions an Introduction to the Comparative Study of their History and Existing Form, London: Fith Printed, Sidwick \& Jackson Limited.

\section{Lain-Lain}

[16]Hadjon, Philipus M. (1997). Pengkajian Ilmu Hukum, Makalah, Pelatihan Metode Penelitian Hukum Normatif, Surabaya: Universitas Airlangga

[17]Hadjon, Philipus M. (2004), Kedudukan Undang-Undang Pemerintahan Daerah Dalam Sistem Pemerintahan, disampaikan dalam Seminar Sistem Pemerintahan Indonesia Pasca Amandemen UUD 1945 diselenggarakan oleh Badan Pembinaan Hukum Nasional Departemen Kehakiman dan Hak Asasi Manusia R.I. Bekerjasama dengan Fakultas Hukum Universitas Airlangga dan Kantor Wilayah Departemen Kehakiman dan Hak Asasi Manusia Provinsi Jawa Timur, Surabaya.

[18]Kertapradja, E. Koswara. (2007). Pokok-pokok Pikiran dalam Permasalahan Kedudukan Gubernur sebagai Wakil Pemerintah Pusat, Makalah dipersiapkan untuk bahan masukan pembahasan Revisi UU No. 32 Tahun 2004, Roundtable Meeting.

[19] Manan, Bagir. (1994). Hubungan Antara Pusat Dan Daerah Menurut UUD 1945, Jakarta: Pustaka Sinar Harapan.

[20] Manan, Bagir. (2004), Menyongsong Fajar Otonomi Daerah, Yogyakarta: Pusat Studi Hukum Faluktas Hukum Universitas Islam Indonesia.

[21]Maksum, Irfan Ridwan. (2009). Perbandingan Sistem Pembagian Urusan Pemerintahan Antara Pemerintah Pusat Dan Daerah Otonom,_Laporan DSF Bank Dunia. 